Agnieszka Jędrzejewska

Stowarzyszenie Historyków Wojskowości

iD ORCID ID: 0000-0002-7748-2066
OBLICZA WOJNY

TOM $3 \cdot$ MIASTO I WOJNA

ŁÓDŹ2021 • ISBN 978-83-8220-556-5 • s. 209-227

https://doi.org/10.18778/8220-556-5.12

\title{
GRODNO - ZAPOMNIANY GARNIZON II RZECZPOSPOLITEJ. WYJĄTKI Z DZIEJÓW
}

Streszczenie. W latach II Rzeczypospolitej w Grodnie istniał jeden z największych garnizonów wojskowych. O jego sile i znaczeniu świadczyła obecność regularnych oddziałów wojska oraz władze i instytucje wojskowe, które w tym mieście miały swoje siedziby. Związanych z nim było wielu znanych oficerów, którzy aktywnie uczestniczyli w życiu miasta. Historia garnizonu pełna jest takich wydarzeń jak codzienna służba, sprawy wyszkolenia i dyscypliny, edukacji i wychowania żołnierzy. To także sport i udział oficerów garnizonu w różnych wydarzeniach wykraczających poza codzienną służbę. Tak obszerna tematyka przekracza ramy prezentowanego tekstu, dlatego przedstawione wątki są jedynie niewielkim wycinkiem historii garnizonu, który we wrześniu 1939 r. przestat istnieć i nie odrodził się już po 1945 r.

Słowa kluczowe: Grodno, Garnizon Grodno, Wojsko Polskie 1921-1939

Grodno to jeden z największych ośrodków miejskich, jakie znajdowały się na wschodnich terenach II Rzeczypospolitej ${ }^{1}$. Na mocy postanowień traktatu ryskiego, w marcu $1921 \mathrm{r}$. miasto znalazło się w granicach państwa polskiego i zostało włączone do województwa białostockiego na prawach miasta powiatowego. Posiadało niejednolitą strukturę etniczną. Według danych statystycznych z 1931 r. liczyło 49,7 tys. mieszkańców². Z tej liczby najwięcej było Polaków, znacznie mniej Białorusinów i Rosjan. Znaczącą grupę stanowili

${ }^{1}$ W tekście zastosowano następujące skróty: BK - Brygada Kawalerii, CAW WBH - Centralne Archiwum Wojskowe - Wojskowe Biuro Historyczne, DOK - Dowództwo Okręgu Korpusu, DP - Dywizja Piechoty, MWRiOP - Ministerstwo Wyznań Religijnych i Oświecenia Publicznego, OK - Okręg Korpusu, PTH - Polskie Towarzystwo Historyczne, pal - pułk artylerii lekkiej, pp - pułk piechoty, WKS - Wojskowy Klub Sportowy.

${ }^{2}$ Maty rocznik statystyczny 1938, Warszawa 1938, s. 40. 
Żydzi ${ }^{3}$. Grodno to także dzieje garnizonu, którego historia jest obszerna i wielowątkowa. Już sama ilość jednostek i instytucji wojskowych w nim stacjonujących wskazuje, jak trudne jest opracowanie w sposób wyczerpujący całości zagadnień, które ich dotyczą. Skupienie się tylko na regularnych oddziałach wojska wymaga poruszenia takich kwestii jak historia ich sformowania, struktura, dowództwo, wyszkolenie, codzienna służba, sport, udział w życiu miasta, sprawy dyscypliny i wychowania żołnierzy. Nie bez znaczenia pozostają też niektórzy dowódcy i przebieg ich służby. Bazę źródłową do opracowania powyższego tematu stanowi przede wszystkim zasób Centralnego Archiwum Wojskowego, gdzie znajdują się liczne dokumenty dotyczące Komendy Garnizonu Grodno, 29. DP, 76. pp i 81. PSG (dalej: 81. pp), 29. pal oraz DOK nr III. Przydatne są także akta personalne i odznaczeniowe dowódców, natomiast pewna część dokumentów wytworzonych przez polskie władze wojskowe znajduje się w Narodowym Archiwum Historycznym Białorusi w Grodnie. Wiele informacji na temat funkcjonowania garnizonu odnaleźć można również w przedwojennej prasie, dostępnej w zasobach bibliotek stacjonarnych i cyfrowych. Mimo obszernej bazy źródłowej garnizon grodzieński praktycznie nie istnieje w polskiej historiografii. Odnieść można nawet wrażenie, że jego dzieje pozostają od lat na marginesie badań historyków wojskowości. Świadczy o tym brak jakiejkolwiek monografii naukowej poświęconej temu garnizonowi, jednostkom czy którejś z instytucji wojskowej stacjonujących w tym mieście. O nikłym zainteresowaniu tym tematem świadczy także skromna literatura, głównie o charakterze popularnym i wspomnieniowym, traktująca dzieje garnizonu bardzo ogólnie ${ }^{4}$. Jest ona niewspółmiernie mała wobec szerokiej problematyki badawczej w tym zakresie, którą należałoby podjąć. Obecnie jednak przedstawienie dziejów całego garnizonu na przestrzeni prawie dwudziestu lat

${ }^{3}$ Cf., przybliżone dane - R.J. Czarnowski, Grodno. Zapomniana stolica, Warszawa 2015, s. 92-93.

${ }^{4}$ Vide m.in.: J. LisICKI, Strzelcy grodzieńscy, Białystok 1995; J.J. MiLEwski, Udziat oficerów garnizonu grodzieńskiego $w$ życiu kulturalnym miasta $w$ latach trzydziestych, [w:] Ksiega jubileuszowa Muzeum Wojska 1968-1998, Białystok 1999, s. 195-197; A. GAPONIK, T. GAPONIK, Grodno na starej fotografii, Katowice 2013; Z. KOPOCIŃSKI, K. KOPOCIŃSKI, Losy ostatniego szefa oddziatu chirurgicznego 3. Szpitala Okregowego w Grodnie pptk. Adama Kietbińskiego (1894-1975) jako odbicie dziejów polskiej wojskowej stużby zdrowia z Kresów Wschodnich II Rzeczpospolitej, „Acta Medicorum Polonorum” 2018, nr 8, z. 1, s. 55-66; IDEM, „Przywieziono nas gdzieś do lasu, coś w rodzaju letniska” - w hotdzie pptk. Dr Dionizemu Krechowiczowi (1896-1940), ostatniemu komendantowi 3. Szpitala Okregowego w Grodnie, „Lekarz Wojskowy” 2019, nr 97, z. 1, s. 89-96. 
nie jest możliwe z powodu braku dostępu zarówno do zbiorów archiwalnych, jak i bibliotecznych. Zaprezentowanie z kolei wszystkich zagadnień zdecydowanie przekracza ramy powyższego tekstu, dlatego przedstawione zostały tylko wybrane i nieliczne wątki z bogatej historii garnizonu, jako zapowiedź systematycznych badań.

Grodno z różnych powodów zasługuje na uwagę, choć w II Rzeczypospolitej budziło skrajne uczucia - od zachwytu po całkowitą dezaprobatę. O wątpliwej urodzie miasta jednoznacznie wypowiedziała sięZofia Nałkowska, pisarka, żona płk. Jana Gorzechowskiego, dowódcy 3. Dywizjonu Żandarmerii. W związku z objęciem przez męża tego stanowiska, wraz z nim zamieszkała w Grodnie. Z wyjątkiem Starego i Nowego Zamku nad Niemnem, które uważała za najpiękniejsze obiekty, miała o tym mieście jak najgorsze zdanie. W swym dzienniku pod datą 15 września 1923 r napisała:

Grodno jest daleko brzydsze niż Wilno. (...) mieszkam w tym mieście, które położone jest prześlicznie, a zabudowane w sposób okropny, brudne, cuchnące, obdrapane przez ludzi. Koło drewnianego domku Orzeszkowej i paru przy nim starych drzew przejeżdżam ze smutnym wzruszeniem. Dziwię się, że właśnie tutaj tak chciała być do końca, że to miasto było jej ojczyzną̧5

Innego zdania był aktor i reżyser Juliusz Osterwa, który w liście z 14 września 1926 r. do swej córki Elżbiety pisał m.in.: „Chciałbym, żebyś poznała Grodno. Mieścina to niewielka, podobna do Wilna. Prześlicznie położona nad cudnymi brzegami Niemna. Ja się tu czuję dobrze, może lepiej niż w Wilnie"6.

Tak czy inaczej, mimo zróżnicowanych i nie zawsze przychylnych opinii, w marcu 1921 r. Grodno rozpoczęło swą egzystencję w odrodzonej II Rzeczypospolitej. Początki nie były łatwe. Niewystarczające środki na likwidację szkód wojennych i odbudowę miejskiej infrastruktury sprawiły, że już w pierwszych latach Grodno postrzegane było jako brzydkie i zaniedbane. Pomimo trudności podejmowane były starania o zmianę wizerunku i jego przyszłej pozycji - miasta, w którym rozwijał się przemysł, handel, powstawały szkoły, instytucje kultury mające także ambicje naukowe. Najbardziej znane fabryki, które rozsławiły Grodno w całej Polsce, to m.in. Zjednoczone Huty Szkła (d. „Łosośna)

${ }^{5}$ Z. NaŁKOWsKa, Dzienniki 1918-1929, Warszawa 1980, s. 103.

${ }^{6}$ Cyt. za: Pamięć Grodna 1919-1939. Informator wystawy luty-kwiecień 1999, Warszawa 1999, s. 36 . 
i Krajowa Fabryka Kart do Gry „Aleksander Łapin i Ska”. Ta ostatnia firma przyjmowała także zamówienia na usługi litograficzne w postaci etykiet, plakatów, druków reklamowych. Drukowała także niektóre grodzieńskie dzienniki, których ukazywało się w Grodnie co najmniej kilkanaście. Były to m.in. „Nadniemeński Kurier Polski”, „Głos Nadniemeński”, „Nowy Kurier Grodzieński”, „Wiadomości Grodzieńskie” czy „Echo Grodna”. Równie wielkie uznanie zyskały wyroby Kresowej Fabryki Rowerów i Motocykli „Niemen”. Poważną natomiast inwestycją było wykupienie w $1924 \mathrm{r}$. przez polski rząd trzech firm tytoniowych i utworzenie jednej Państwowej Fabryki Wyrobów Tytoniowych. Grodno było także dużym ośrodkiem kultury polskiej. Istniały tu i prężnie działały takie instytucje jak Teatr Miejski im. Elizy Orzeszkowej oraz mieszczące się w Starym Zamku Muzeum Historyczne i Muzeum Przyrodnicze.

Wszystkie działania i wysiłki o charakterze gospodarczym, społecznym, kulturalnym sprawiły, że Grodno, mimo swego oddalenia od centrum kraju i innych, dużych ośrodków nie miało charakteru miasta prowincjonalnego. Wkrótce jego dodatkowym atutem stało się wojsko. Dyslokowanie w tym miejscu regularnych jednostek oraz wielu instytucji wojskowych podniosło prestiż miasta i zmieniło jego dotychczasowy charakter. W Grodnie stacjonowały dwa pułki piechoty: 81. pp, 76. Lidzki Pułk Piechoty im. Ludwika Narbutta (dalej: 76. pp) oraz 29. pal (bez I dywizjonu, który stacjonował w Suwałkach). Te trzy jednostki wchodziły w skład 29. DP, której dowództwo również znajdowało się w mieście. Od 1935 r. w Grodnie stacjonował także 7. Batalion Pancerny. Tu także była siedziba dowódcy OK nr III, któremu podlegały administracyjnie trzy dywizje piechoty (1., 19. i 29. DP), trzy brygady kawalerii (Wileńska, Suwalska i Podlaska) oraz liczne instytucje wojskowe i inne jednostki rozmieszczone na obszarze wspomnianego okręgu obejmującego obszar trzech województw: białostockiego, wileńskiego i części nowogródzkiego". Oprócz regularnych jednostek wojska, w Grodnie zostały dyslokowane m.in.: 2. Dywizjon Artylerii Przeciwlotniczej, 3. Dywizjon Żandarmerii, 3. Batalion Sanitarny, dowództwo

7 Vide: T. KAZAK, Katalog prasy grodzieńskiej, „Rocznik Grodzieński” 2019, nr 5, s. 89-115.

8 Vide: A. Waszkiewicz, Kresowa Fabryka Rowerów i Motocykli „Niemen”, „Rocznik Grodzieński” 2019, nr 5, s. 121-130; Żadajcie wyrobów Kresowej Fabryki Rowerów i Motocykli „Niemen”, [reklama], „Głos Nadniemeński” 1938, nr 1, s. 12.

9 K. FILIPOW, Barwa, herby i godta na odznakach Wojska Polskiego w DOK nr III - Grodno, [w:] SGO „Narew” i GO „Grodno” w wojnie obronnej 1939 r. Materiaty z sesji naukowej „Obchody 65 rocznicy wybuchu II wojny światowej", Białystok-Przasnysz 2004, s. 87-100. 
Korpusu Ochrony Pogranicza „Grodno” oraz 3 Szpital Okręgowy usytuowany w pomieszczeniach Nowego Zamku ${ }^{10}$.

Powstanie garnizonu zapoczątkowało nowy etap w dziejach Grodna, a sam garnizon w krótkim czasie stał się jednym z największych w II Rzeczpospolitej. O przeobrażeniach miasta z tym związanych kolejny raz głos zabrała Z. Nałkowska, która m.in. krytycznie wypowiedziała się o budynkach koszarowych „Z szarej cegły, szpetnych i smutnych”11. Niezależnie jednak od ocen i wrażeń estetycznych obecność wojska w Grodnie stała się faktem oraz ważnym elementem życia codziennego. Świadectwem i pamiątką tamtych lat pozostały fotografie grodzieńskich żołnierzy wykonane w czasie służby, jak i w chwilach wolnych od obowiązków.

Zwyczaj sprawiania sobie pamiątkowych zdjęć stał się niemal codzienną praktyką zakładów fotograficznych w mieście, a żołnierze stanowili ich liczną klientelę. Do dziś zachowało się wiele takich fotografii, których autorami byli ci najbardziej znani i popularni w Grodnie: Michał Arcysewicz, Dominik Aneryk, Izrael Chomul, Lejb Gelgor, Zelman Karasik czy Mikołaj Rubinstein. Ich dziełem były nie tylko żołnierskie portrety, często wyróżniające się wysokim poziomem artystycznym. Wielu z nich utrwaliło także ulice i najciekawsze miejsca w Grodnie, które przetrwały do chwili obecnej w postaci widokówek ${ }^{12}$. Fotografem, który uwieczniał wojsko nie tylko w swoim atelier, ale także w koszarach i w czasie zajęć służbowych poza nimi, był wspomniany wcześniej D. Aneryk. Jako ciekawostkę należy dodać, że w sierpniu 1938 r. wydał za mąż swą córkę Reginę za niejakiego kpt. Czesława Michalczyka, oficera 81. pp ${ }^{13}$, który z pewnością wcześniej także zawitał do jego zakładu.

Związki grodzieńskich zakładów fotograficznych z garnizonem to odrębna opowieść. Jednak mówiąc krótko - wojsko lubiło się fotografować, głównie na pamiątkę służby, ważnych wydarzeń czy rocznic. Obok prywatnych, zdarzało się, że dowództwa jednostek zamawiały pojedyncze zdjęcia, przede wszystkim oficerów i podoficerów. Z fotografii tych tworzono następnie albumy albo tzw.

${ }^{10}$ Vide: S.S. NicIEJA, Grodzieńscy lekarze wojskowi, [w:] Kresowa Atlantyda. Historia i mitologia miast kresowych, t. 13, Grodno, Wotczyn, Stare Wasiliszki, Żotudek, Mosty, Druskienniki, Opole 2019, s. 137-139.

${ }^{11}$ Z. NAŁKOwSKA, Grodno, „Tygodnik Ilustrowany” 1936, nr 45, s. 765.

12 https://harodnia.com/pl/grodno-wczoraj/520-od-zdjecia-z-fotosalonu-do-filmowki (dostęp: 5 I 2021).

13 CAW WBH, 81 pp, I.320.81.23, Rozkaz nr 182 z 12 VIII 1938 r., karty bez paginacji. 
tableau. Z taką propozycją wyszedł m.in. ppłk Antoni Wandtke, p.o. dowódcy 81. pp, który w początkach maja 1935 r. zwrócił się do swych podwładnych z następującym apelem: „Przypominam, że do dnia 8 V 1935 r. powinni wszyscy oficerowie udać się do fotografa Rubinstejna celem dokonania zdjęć do albumu. Do dnia dzisiejszego sfotografowało się - 25 ofic." ${ }^{14}$. Natomiast płk Stanisław Czuryłło, dowódca 76. pp, nawiązując do dwudziestej rocznicy powstania pułku, stwierdził, że wspólna fotografia wszystkich oficerów i podoficerów pułku byłaby miłą pamiątką służby dla każdego z nich, i należałoby ją zawiesić także na ścianach kasyn. Poprosił więc, by „wszyscy PP oficerowie i podoficerowie pułku (sł. stałej) złożyli do dnia 30 I br. [1939 - A.J.] swoje fotografie z pełnymi odznaczeniami w formacie kartki 9x12, oficerowie do adiutanta pułku, podoficerowie u sierż. Niesłuchowskiego z kanc. Pułku. Dla ułatwienia zrobienia zdjęć tym, którzy nie posiadają fotografii sprowadzony będzie do pułku fotograf"15. Nie wiadomo, czy zaplanowane pamiątkowe fotografie zostały wykonane. Jak dotąd, w zachowanych źródłach, przekazach i dostępnych kolekcjach brak informacji na ten temat oraz śladów takich obiektów.

Ciekawym wątkiem w dziejach garnizonu grodzieńskiego były sprawy związane ze sportem. Liczne zajęcia ruchowe, w których uczestniczyli żołnierze, wskazują, że był to jeden z garnizonów, w którym sprawy sportu znajdowały się na czołowym miejscu w procesie wyszkolenia ${ }^{16}$. Żołnierze - oficerowie, podoficerowie i szeregowi - uprawiali różne dyscypliny: gry zespołowe, jazdę konną, szermierkę, kolarstwo, boks, pływanie i wioślarstwo. W okresie zimowym zdobywali umiejętności jazdy na nartach. Zajęcia te znajdowały się programie wyszkolenia, więc były obowiązkowe. Głównym celem było podniesienie sprawności fizycznej. O ile jazda konna należała do obowiązkowych umiejętności, jaką musieli wykazywać się oficerowie, to takie dyscypliny jak boks, szermierka czy pływanie były czymś rzadko spotykanym w planie wyszkolenia wojska.

Dowódcy przywiązywali dużą wagę do sztuki pływania. Według opinii m.in. płk. dypl. Stanisława Maczka, dowódcy 81. pp była to umiejętność niezbędna dla każdego żołnierza w każdych warunkach służby. Zdobycie tej sprawności było obowiązkiem, do którego kazał się bezwzględnie stosować, zwłaszcza

\footnotetext{
14 Ibidem, 81 pp, I.320.81.16, Rozkaz dzienny nr 101 z 7 V 1935 r. (awizo), karty bez paginacji.

15 Ibidem, 76 pp, I.320.76.17, Rozkaz dzienny nr 17 z 23 I 1939 r., karty bez paginacji.

16 Cf. - J. LisICKI, op. cit., s. 26-28.
} 
podoficerom. Jak zapowiadał, jeśli „nie wykażą się umiejętnością przepłynięcia $100 \mathrm{~m}$ stylem dowolnym na wodzie stojącej otrzymają ujemne kwalifikacje jako nieposiadający dostatecznej sprawności fizycznej”17. Problem dotyczył także oficerów. Wszyscy oporni, którzy nie osiągali wymaganych wyników, kierowani byli na obowiązkową naukę pływania. Płk. S. Maczek stawiał sprawę jasno: „Na kurs obowiązani są uczęszczać panowie, którzy nie pływają, lub też, którzy podczas zawodów nie przepłynęli $300 \mathrm{mtr}{ }^{\prime 18}$.

Jak widać, umiejętności sportowe miały swoje znaczenie, dowódcy natomiast wymagania. Dlatego szkolenia, kursy, a następnie regularne treningi traktować należało jak rozkaz. Dla żołnierzy garnizonu Grodno organizowane były zatem kursy pływania, ale też bokserskie, szermiercze, narciarskie. Zajęcia teoretyczne odbywały się w koszarach, praktyczne - w terenie i na zawodach, co zresztą też było obowiązkowe. Obecność wszystkich wyznaczonych na dane zajęcia była bezdyskusyjna. W ten sposób żołnierze-zawodnicy rywalizowali w zawodach bokserskich w różnych kategoriach wagowych, pływackich, szermierczych, konnych, nie mówiąc o kolarskich wyścigach szosowych, biegach narciarskich i przełajowych.

W krótkim czasie zajęcia sportowe przybrały bardziej formalny kształt organizacyjny. Zaczęły powstawać sekcje różnych dyscyplin: kolarska, szermiercza czy wioślarska (przekształcona następnie w Wioślarski Klub „Grodno”), natomiast 26 marca 1934 r. został utworzony Wojskowy Klub Sportowy „Grodno” Wyznaczeni przez dowództwo swych jednostek żołnierze - oficerowie, podoficerowie i szeregowi, odbywali regularne, codzienne treningi, głównie w godzinach popołudniowych. Często zwalniani byli nawet z zajęć, jeśli je w tym czasie mieli. Tak było w przypadku osady wioślarskiej złożonej z oficera, podoficera i pięciu strzelców, w tym jednego członka orkiestry pułkowej 81. pp. W ramach przygotowań do zawodów zaplanowanych w pierwszych dniach lipca 1931 r., codziennie odbywali treningi na Niemnie ${ }^{20}$.

Z całą pewnością bliskie sąsiedztwo rzeki sprawiało, że sporty wodne cieszyły się popularnością i były okazją do organizowania dużych imprez. Każdego roku wydarzeniem znacznej rangi w garnizonie było otwarcie sezonu wioślarskiego.

17 CAW WBH, 81pp, I.320.81.11, Rozkaz dzienny nr 169 z 2 VIII 1932 r., karty bez paginacji.

18 Ibidem, 81pp, I.320.81.10, Rozkaz dzienny nr 170 z 29 VII 1931 r., karty bez paginacji.

19 Ibidem, 81pp, I.320.81.14, Rozkaz dzienny nr 74 z 4 IV 1934 r., karty bez paginacji.

${ }^{20}$ Ibidem, 81pp, I.320.81.9, Rozkaz dzienny nr 143 z 31 VI 1931 r., karty bez paginacji. 
W początkach maja 1935 r. inauguracji towarzyszyła wyjątkowa oprawa. Program przewidywał następujące punkty: przemówienie Prezesa Klubu, złożenie przyrzeczenia wioślarskiego, defiladę łodzi i kajaków oraz spacer statkiem klubowym po Niemnie ${ }^{21}$. W dniu 5 lipca 1936 r. odbyły się natomiast wyjątkowe zawody pływackie o nazwie „Wpław przez Grodno”, w dokumentach określone jako „propagandowe”. Były to zawody indywidualne i zespołowe, a na starcie stanęli oficerowie i podoficerowie garnizonu. Pierwsze miejsce w kategorii zespołowej wygrał zespół 81. pp, o czym nie bez satysfakcji poinformował płk dypl. S. Maczek, dowódca pułku²2.

Oprócz imprez sportowych, w których reprezentanci garnizonu rywalizowali w różnych dyscyplinach, niektóre służyły rekreacji i zacieśnianiu więzi między członkami garnizonowej społeczności. Udział w nich należał do dobrego tonu i był jednym z obowiązków członków rodzin oficerskich i podoficerskich. Tak było m.in. w związku z - jak to zostało określone - „towarzyską wycieczką rowerami do Jezior”, całodzienną, którą na dzień 1 lipca 1934 r. zaplanowało kierownictwo Sekcji Kolarskiej WKS „Grodno”. Podkreślono też, że „jest bardzo pożądanem wzięcie jak najliczniejszego udziału przez podoficerów, o ile możności z żonami lub znajomymi”23.

Wojsko aktywnie uczestniczyło w życiu miasta, co było naturalne także w innych garnizonach. Obok obowiązków służbowych, zwłaszcza oficerowie aktywnie wspierali różne inicjatywy, głównie w zakresie kultury. W Grodnie kontakty wojska z mieszkańcami i przedstawicielami różnych miejskich instytucji układały się wyjątkowo dobrze. Wspominał o tym gen. dyw. inż. Leon Berbecki, dowódca OK nr III w latach 1924-1926, który zanotował na ten temat następujące spostrzeżenia:

Wszystkie odłamy społeczeństwa grodzieńskiego do wojska polskiego ustosunkowały się przyjaźnie. (...) Nad wszystkimi panowała pamięć o wielkiej pisarce Elizie Orzeszkowej, której wpływ godził i uszlachetniał wszelkie plany i dążenia kulturalne i społeczne. (...) Przedstawiciele obywatelstwa miejscowego (...) wspólnie

${ }^{21}$ Ibidem, 81 pp, I.320.81.16, Rozkaz dzienny nr 98 z 2 V 1935 r. (awizo), karty bez paginacji.

${ }^{22}$ Ibidem, 81 pp, I.320.81.19, Rozkaz dzienny nr 146 z 2 VII 1936 r. i Rozkaz dzienny nr 148 z 6 VII 1936 r., karty bez paginacji.

${ }^{23}$ Ibidem, 81 pp, I.320.81.14, Rozkaz dzienny nr 143 z 27 VI 1934 r. (awizo), karty bez paginacji. 
z oficerami dwudziestej siódmej dywizji (sic!) i dowództwem korpusu, wspomagali działalność teatru miejskiego, kierowali sprawą urządzania wycieczek do miejscowości historycznych i malowniczych zakątków na Niemnie i jego dopływach ${ }^{24}$.

Mimo tak pochlebnych opinii gen. L. Berbecki już w pierwszym roku swego urzędowania musiał zmierzyć się z problemem uregulowania statusu Starego Zamku w Grodnie, czego domagał się Józef Jodkowski, konserwator obiektu. Wiele pomieszczeń zamkowych użytkowanych było przez wojsko. Mieściło się tu kasyno i hotel oficerski, całe zaplecze administracyjne oraz biblioteka Towarzystwa Wiedzy Wojskowej. Istotą całej sprawy było przejęcie Starego Zamku od wojska i przeprowadzenie niezbędnych prac konserwatorskich, a ponadto umieszczenie w jego salach muzeum i przeznaczenie obiektu na cele reprezentacyjne i kulturalne. W połowie sierpnia 1924 r. J. Jodkowski złożył do Rady Miejskiej Grodna wniosek w tej sprawie, podkreślając, że instytucja wojskowa, jaką w tym przypadku było DOK nr III, traktuje Zamek jako obiekt użytkowy, tylko częściowo reprezentacyjny, a nie jako zabytek historyczny. Pojawił się także zarzut, że władze wojskowe nie dbały o Zamek ani o jego pierwotny wygląd i charakter, który bardziej był zbliżony „do koszarowego stylu doby dzisiejszej” 25 .

Kolejnym argumentem przemawiającym za koniecznością otoczenia obiektu opieką konserwatorską było zagrożenie wzgórza zamkowego. Jak twierdził J. Jodkowski:

skutkiem bezplanowych robót budowlano-ziemnych prowadzonych przez wojskowość bez specjalnej naukowej kontroli i wskazówek oraz skutkiem stałego osuwania się góry do Niemna, grozi z czasem, w razie systematycznego niezabezpieczenia i nie umocnienia gruntowego skarp i lochów, ten sam los pozostałej resztce Zamku, jaki spotkało te jego skrzydła, które ongiś stanowiły całość budowli, a które dzięki brakowi opieki wraz z częścią góry zamkowej zapadły się do Niemna ${ }^{26}$.

Z wywodów J. Jodkowskiego wynikało, że wojsko eksploatowało Stary Zamek bez oglądania się na jego historyczną przeszłość i zabytkowy charakter. Dotknięty nieco taką oceną gen. L. Berbecki powołał specjalną komisję, która miała zbadać stan pomieszczeń i samego wzgórza. W dniu 24 sierpnia 1924 r.

\footnotetext{
24 L. BerBeCKI, Pamiętniki generata broni, Katowice 1959, s. 197.

25 Dwie donioste uchwaty Rady Miejskiej, „Nadniemeński Kurier Polski” 1924, nr 16, s. 1.

26 Ibidem.
} 
generał przedstawił raport, w którym zaproponował plan prac, jakie miały być wykonane przez wojsko. Komisja zdecydowała wówczas o przeniesieniu kasyna oficerskiego do pomieszczeń na parterze budynku, odrestaurowanych na wzór dawnych sal rycerskich. Hotel miał być przeniesiony w inne miejsce. Planowano urządzić go w nowym lokalu, możliwie blisko dworca kolejowego. Natomiast odpowiedzialność za zabezpieczenie wzgórza zamkowego spoczęła na Szefie Inżynierii i Saperów DOK III ${ }^{27}$, który wraz z przedstawicielami Departamentu Kultury i Sztuki Ministerstwa Wyznań Religijnych i Oświecenia Publicznego oraz Zarządu Dróg Wodnych miał za zadanie sporządzenie niezbędnej dokumentacji oraz rozpoczęcie pierwszych prac ziemnych ${ }^{28}$.

Rada Miejska pozytywnie odniosła się do decyzji gen. L. Berbeckiego i skierowała odpowiednie pismo do MWRiOP w sprawie Zamku. Zaznaczyła także, że wojsko nadal będzie mogło korzystać z pomieszczeń do celów reprezentacyjnych. W przeciwieństwie do przedstawicieli miejskiego samorządu, J.Jodkowski odnosił się z rezerwą do komisji gen. L. Berbeckiego. Bywało, że nie uczestniczył w jej zebraniach, mimo że jego współpraca z tym gremium jako konserwatora w już rozpoczętych pracach remontowych była wręcz niezbędna. Atmosfera między stronami nieco się poprawiła, gdy 22 września 1924 r. prasa grodzieńska opublikowała oświadczenie J. Jodkowskiego. W pojednawczym tonie, zwracając się do przedstawicieli sejmików powiatowych i magistratów województwa białostockiego, konserwator i kustosz Starego Zamku podkreślił wolę niesienia pomocy ze strony gen. L. Berbeckiego w dziele przywrócenia świetności tego obiektu i jego właściwego użytkowania w przyszłości. Wyraził też nadzieję, że postawa przedstawicieli władz wojskowych znajdzie swoich naśladowców wśród działaczy samorządowych ${ }^{29}$.

Idea opieki nad Starym Zamkiem łączyła wojsko i władze miasta jeszcze przez wiele lat. Organizowane były spotkania dotyczące historii tego zabytku oraz postępu prac przy jego renowacji. Zbierane były też środki na ten cel. M.in. 11 lutego 1938 r. w Sali Teatru Miejskiego Jarosław Wojciechowski, profesor Politechniki Warszawskiej i przewodniczący Komisji Badań i Komisji Technicznej oraz Witold Kieszkowski, konserwator wojewódzki, przygotowali

\footnotetext{
${ }^{27}$ W latach 1922-1929 był nim płk Franciszek Wolf.

${ }_{28}$ Projekty i postanowienia w sprawie Zamku, „Nadniemeński Kurier Polski” 1924, nr 31, s. 1 .

29 Odezwa do Sejmików Powiatowych i Magistratów miast wydzielonych Województwa Biatostockiego, „Nadniemeński Kurier Polski” 1924, nr 60, s. 1.
} 
odczyt pt. „Prace na Królewskim Zamku Starym w Grodnie”, o czym poinformowały swoich podwładnych władze wojskowe, zachęcając do udziału w tym spotkaniu. Cały dochód ze sprzedaży biletów wstępu został przeznaczony na prace konserwatorskie na Zamku ${ }^{30}$.

W początkach października 1926 r. gen. dyw. L. Berbecki zakończył swą misję w Grodnie i otrzymał przydział na równorzędne stanowisko w Toruniu, tj. dowódcy OK nr VII. Jednym z jego następców w latach 1927-1935 został gen. bryg. Aleksander Litwinowicz. Był postacią popularną w mieście. Patronował wielu imprezom o charakterze reprezentacyjnym, które organizował garnizon grodzieński. Jedną z nich był coroczny bieg myśliwski św. Huberta. Program zaplanowany na 31 października 1932 r. przewidywał dwie kategorie: „a) bieg lekki - dla oficerów (nie jezdnych broni), pań i panów. Dystans 4 km, 10 przeszkód o wysokości do $90 \mathrm{~cm}$; b) bieg ciężki - dla oficerów (broni jezdnych i życzących [sobie - A.J.], pań i panów. Dystans $6 \mathrm{~km}, 18$ przeszkód o wysokości $1 \mathrm{~m} 50 \mathrm{~cm}^{\text {"31 }}$.

W sprawie Starego Zamku, wzorem swego poprzednika gen. L. Berbeckiego, gen. A. Litwinowicz kontynuował współpracę przy odnowieniu obiektu. Zaangażowany był w podobne działania przy Farze Witoldowej. Przyczynił się także do budowy kasyna garnizonowego, które zostało uroczyście otwarte 9 lutego 1935 r. w nowej siedzibie przy ul. Piłsudskiego w Grodnie ${ }^{32}$.

Współpraca władz wojskowych, które w Grodnie reprezentował w tym okresie gen. A. Litwinowicz, z władzami miasta, przebiegała bez większych problemów. Dowództwo OK nr III i Komenda Garnizonu dokładały starań, by tak liczne zgromadzenie żołnierzy nie zakłócało życia miasta i jego mieszkańców. Wprawdzie jak wszędzie zdarzały się incydenty w miejscach publicznych, ale dowództwo starało się minimalizować żołnierskie występki poprzez zakazy i konsekwencje dyscyplinarne. M.in. wyznaczone były miejsca, po których wolno było poruszać się żołnierzom na przepustkach. Jak to określił krótko płk. dypl. S. Maczek - należało „dopilnować, aby szeregowi bez potrzeby nie wałęsali się

${ }^{30}$ CAW WBH, 81 pp, I.320.81.22, Rozkaz dzienny nr 38 z 10 II 1938 r. (awizo), karty bez paginacji.

${ }^{31}$ Ibidem, 81 pp, I.320.81.11, Rozkaz dzienny nr 226 z 25 X 1932 r. (awizo), karty bez paginacji.

${ }^{32}$ Ibidem, 81 pp, I.320.81.16, Rozkaz dzienny nr 32 z 7 II 1935 r., karty bez paginacji; J.J. MILEWSKI, op. cit., s. 195. 
po mieście"33. Ograniczenia objęły także orkiestry wojskowe i żołnierski śpiew. W trosce o spokój mieszkańców komendant garnizonu zabronił oddziałom śpiewać na ulicach miasta, natomiast orkiestry podczas przemarszów mogły grać tylko od godziny 7.00 do $21.00^{34}$.

Miłym gestem i wyrazem wdzięczności za życzliwość i dobrą współpracę było wręczanie przedstawicielom miast, w których stacjonowało wojsko, odznak pułkowych. W Grodnie takie wyróżnienie spotkało Radę Miejską, która 18 stycznia 1934 r. otrzymała pamiątkową odznakę 81. pp. W uchwale Rady, obok podziękowań i wyrazów wdzięczności dla dowództwa i korpusu oficerskiego, znalazło się wiele miłych słów pod adresem pułku. Radni zapewnili o przywiązaniu miasta i jego obywateli do tej jednostki, zadeklarowali „po wsze czasy” nierozerwalną łączność oraz złożyli życzenia dalszej owocnej pracy dla dobra Ojczyzny. Poinformowali także, że dyplom nadania odznaki zawieszony zostanie w sali obrad Rady Miejskiej Miasta Grodna ${ }^{35}$.

Brak w obecnej chwili dostępu do materiałów źródłowych oraz luki w innych przekazach uniemożliwiają przedstawienie szczegółów aktywności gen. A. Litwinowicza na rzecz miasta. Jego praca była z pewnością zauważalna, skoro władze Grodna nagrodziły dowódcę OK nr III honorowym obywatelstwem. Decyzję tę podjęła Rada Miejska w ostatnim dniu października 1935 r. Generał otrzymał nagrodę, gdy był już dowódcą OK nr VI we Lwowie ${ }^{36}$.

Miejscem życia towarzyskiego oficerów garnizonu grodzieńskiego było kasyno. Przeniesienie go - jak już wspomniano wcześniej - do nowego budynku, dawało możliwości spędzania wolnego czasu w sposób ciekawy, o co zabiegało dowództwo OK nr III i komendant garnizonu. W nowej siedzibie znajdowała się biblioteka, sala bilardowa i balowa, a także pomieszczenia oddane do dyspozycji oficerów pułków grodzieńskich. Obiekt ten duży i przestronny uchodził za najbardziej elegancki i reprezentacyjny lokal w mieście. Mimo to frekwencja w kasynie była znacznie niższa od oczekiwanej. Wprawdzie udział w różnych imprezach był w większości wypadków obowiązkowy, a przede wszystkim pożądany z powodów wizerunkowych, to jednak sytuacja była daleka od zadowalającej. Było to przedmiotem troski m.in. gen. bryg. Franciszka Kleeberga, jednego

33 CAW WBH, 81pp, I.320.81.10, Rozkaz dzienny nr 181 z 11 VIII 1931 r., karty bez paginacji.

34 Ibidem, 81 pp, I.320.81.9, Rozkaz dzienny nr 138 z 20 VI 1931 r., karty bez paginacji.

35 Ibidem, 81 pp, I.320.81.13, Rozkaz dzienny nr 41 z 20 II 1934 r., karty bez paginacji.

36 Obywatelstwo honorowe Grodna, „Kurier Warszawski. Wydanie poranne” 1936, nr 20, s. 6. 
z komendantów garnizonu, który zwracał uwagę, że „kasyno nie tylko ma służyć do urządzania dorywczych imprez, a winno każdego dnia ogniskować w sobie życie kulturalne i towarzyskie oficerów i ich rodzin" ${ }^{37}$. Wyrażał także dezaprobatę dla tych oficerów, którzy w miejskich lokalach, często nie najwyższego lotu, ulegali „namiętności hazardu”, grając w karty na pieniądze z przypadkowymi ludźmi. Zabronił hazardu karcianego, co w niewielkim stopniu wpłynęło na zwyczaje w tym zakresie.

Bez względu na próby poprawy frekwencji podejmowane przez dowództwo garnizonu, zarząd kasyna realizował inicjatywy, które miały zmienić przyzwyczajenia oficerów. W salach kasyna odbywały się tzw. sobótki (sobotnie spotkania towarzyskie oficerów i ich rodzin), odczyty, bale i koncerty, na które często zapraszani byli już uznani artyści lub zapowiadani jako wybitne, młode talenty. Jednym z nich, który koncertował w kasynie oficerskim w Grodnie był nieznany wówczas jeszcze pianista Witold Małcużyński ${ }^{38}$. Artysta wystąpił 23 października 1938 r. zapowiedziany przez „Głos Nadniemeński” jako „największy talent wśród młodych pianistów"39.

Obok odczytów, koncertów, możliwości korzystania z zasobnej biblioteki w kasynie, niektórzy oficerowie mieli ambicje, by rozwijać swe zainteresowania wykraczające poza codzienną służbę. Angażowali się m.in. w prace Polskiego Towarzystwa Historycznego, którego oddział grodzieński powstał dopiero w 1935 r. W jego tworzeniu mieli swój udział: wspomniany wcześniej gen. bryg. A. Litwinowicz, płk. Teodor Furgalski i kpt. Stefan Jellenta, historyk wojskowości, pracownik Wojskowego Biura Historycznego w Warszawie. Członkiem PTH w Grodnie został także gen. bryg. F. Kleeberg. Pułkownik T. Furgalski, który został wybrany na prezesa, miał ambitne plany. Pragnął nadać kierowanemu przez siebie oddziałowi odpowiednio wysoką rangę. Nawiązał w tym

${ }^{37}$ CAW WBH, Komenda Garnizonu Grodno, I. 372.16.15, Rozkaz tajny nr 1 z 19 II 1935 r., karty bez paginacji.

38 Witold Małcużyński (1914-1977), polski pianista. Urodził się w m. Koziczyna k. Święcian. W 1932 r. zdał maturę w Gimnazjum im. Jana Zamoyskiego w Warszawie. Następnie został studentem Konserwatorium Warszawskiego w klasie Józefa Turczyńskiego, które ukończył w 1936 r. z wyróżnieniem. Kształcił się także w Paryżu. W 1937 r. został laureatem III nagrody III Międzynarodowego Konkursie im. Fryderyka Chopina w Warszawie. W 1938 r. odbył tournée po Polsce i wystąpił wówczas z koncertem w Grodnie. Zmarł na Majorce. Pochowany został na Cmentarzu Powązkowskim w Warszawie.

${ }^{39}$ Dnia 23 X b.r. (niedziela) koncertuje w Oficerskim Kasynie Garnizonowym W. Matcużyński. Największy talent wśród mtodych pianistów [ogłoszenie] „Głos Nadniemeński” 1938, nr 21, s. 10. 
celu współpracę z mjr. Ottonem Laskowskim z WBH w Warszawie, zapraszał na zebrania naukowe z odczytami znanych i cenionych historyków, jak przede wszystkim płk. Wacława Lipińskiego, historyka ze stopniem naukowym doktora habilitowanego. Sam płk T. Furgalski wygłaszał wykłady na Uniwersytecie Powszechnym Polskiej Macierzy Szkolnej oraz dla oficerów garnizonu ${ }^{40}$. Z pewnością dużym wsparciem dla grodzieńskiego oddziału PTH było pojawienie się w Grodnie gen. bryg. Józefa Olszyny-Wilczyńskiego, który przybył w lutym 1938 r. i objął stanowisko dowódcy OK nr III. Generał J. Olszyna-Wilczyński miał już doświadczenie w takiej działalności, gdyż wcześniej był członkiem łódzkiego oddziału PTH. Brał także udział w pracach Towarzystwa Przyjaciół Muzeum Wojska w Warszawie. Interesował się historią, pisał artykuły, które zostały opublikowane na łamach jednodniówki „Korpus Ochrony Pogranicza”41. Był także autorem własnych wspomnień zatytułowanych Ze wspomnień lwowskiego drużyniaka 1911-1914 wydanych we Lwowie w 1937 r.

Mimo pasji społecznikowskiej nowego dowódcy OK nr III i ambitnych zamierzeń, nie udało się spopularyzować celów i działalności PTH na tyle, by zwiększyć liczebnie oddział i zachęcić nowych członków do realizacji własnych pomysłów historycznych. Ostatnie zebranie oddziału, któremu przewodniczył gen. J. Olszyna-Wilczyński, odbyło się 30 maja 1939 r. Również wtedy nie spotkało się ono ze szczególnym zainteresowaniem. Z pewnością nie był to dobry czas na rozwijanie takich instytucji jak PTH czy Biblioteka Naukowa, przy tworzeniu której pracowali także oficerowie garnizonu grodzieńskiego wraz z jej pomysłodawczynią Janiną Kozłowską-Studnicką. Już w 1938 r. ważniejsze stały się problemy zagrożenia wojennego spowodowane agresywną polityką Niemiec. Potrzeby armii i państwa odsunęły na bok plany rozwoju instytucji kulturalnych i naukowych. Najważniejsze było skupienie wszystkich wokół spraw państwa i wojska.

Przygotowania wojenne miały swój wymiar propagandowy i finansowy. Zbierane były środki na zakup broni i sprzętu dla armii. W Grodnie również odbywały się zbiórki pieniędzy oraz organizowano przekazywanie sprzętu dla wojska stacjonującego w mieście. Wiele środowisk spieszyło z pomocą i w miarę swoich możliwości gromadziło środki na ten cel. Już w marcu 1938 r. odbyła

\footnotetext{
40 J.J. MiLEWSKI, op. cit., s. 196.

41 Vide: A. JęDRZEJEWskA, Bez prawa do chwaty? Generat brygady Józef Konstanty Olszyna-Wilczyński (1890-1939). Biografia, Łódź 2018, s. 253-261. Tam również bibliografia prac generała, s. 300.
} 
się uroczystość przekazania ciężkiego karabinu maszynowego, ufundowanego przez pracowników Państwowej Fabryki Wyrobów Tytoniowych, a przeznaczonego dla 81. pp. Akt przekazania odbył się na Placu Batorego, w miejscu wielu uroczystości państwowych i wojskowych w Grodnie. Jak zanotował autor relacji $\mathrm{z}$ tego wydarzenia:

Na jezdni obok kościoła farnego stoi nowiuteńki k.m. z biedką i koniem. Wszystko ubrane kwiatami w barwach narodowych, za biedką zaś w dwuszeregu stoi delegacja fabryczna. Po raporcie przedstawiciel fabryki tytoniowej zwraca się do przedstawicieli władz wojskowych o przyjęcie ich skromnego daru. Dowódca O.K. w imieniu wojska dziękuje fundatorom, (...) następnie przekazuje dar ten pułkowi strzelców Grodzieńskich im. Króla Stefana Batorego ${ }^{42}$.

Kilka miesięcy później, 15 maja 1938 r., na stadionie Ośrodka Wychowania Fizycznego odbyła się podobna uroczystość. Tym razem fundatorem ciężkiego karabinu maszynowego, również dla 81. pp, była młodzież grodzieńskich szkół powszechnych i średnich ${ }^{43}$. Rok później, w maju 1939 r., mieszkańcy Skidla za zebrane pieniądze zakupili dwa takie karabiny, które zostały przekazane żołnierzom 76. $\mathrm{pp}^{44}$.

Obok zbiórek pieniężnych, manifestowano przywiązanie do wojska, gotowość pomocy i współdziałania na wypadek wojny. Wydarzeniom tym towarzyszyło patriotyczne uniesienie i wiara, że kraj jest przygotowany na odparcie ewentualnej agresji. Nikt nie przypuszczał, że losy Grodna odmienią się wraz z zatwierdzeniem planów mobilizacji. Szybko bowiem okazało się, że jednostki 29. DP otrzymały przydziały daleko od swego macierzystego garnizonu i będą musiały opuścić miasto. Tak się w istocie stało - zostały wcielone do odwodowej Armii „Prusy” ${ }^{45}$. Gdy rozpoczęła się wojna, żołnierze 76. pp i 81. pp oraz 29. pal (bez I dywizjonu) opuszczali transporty kolejowe w okolicach Skierniewic. W ten sposób, niemalże z dnia na dzień, silny i uzbrojony garnizon stał się

${ }^{42}$ L. KLIN, Wręczenie karabina maszynowego, „Żołnierz Polski” 1938, nr 13, s. 309.

${ }_{43}$ CAW WBH, 81 pp, I.320.81.22, Rozkaz dzienny nr 109 z 14 V 1938 r., karty bez paginacji.

${ }^{44}$ Uroczystość pod tytułem Dary FON dla 76 pp, Skidel k/Grodna, maj 1939 została zarejestrowana we fragmentach na taśmie filmowej znajdującej się obecnie w zasobach Filmoteki Narodowej w Warszawie oraz na kanale YouTube: https://www.youtube.com/watch?v=uz_mMHIjijA (dostęp: 5 I 2021).

45 J. Wróblewski, Armia „Prusy” 1939, Warszawa 1986, s. 24-36; P. Bieliński, 29 Dywizja Piechoty, Warszawa 2018, s. 7-8. 
całkowicie bezbronny, zdany na mieszkańców i niewystarczające siły Ośrodka Zapasowego 29. DP. Los Grodna dopełnił się po agresji sowieckiej 17 września 1939 r. Po dwóch dniach nierównej walki, 22 września do miasta wkroczyła Armia Czerwona ${ }^{46}$.

Wojna, która rozpoczęła się we wrześniu 1939 r., położyła kres istnieniu garnizonu grodzieńskiego. Jego żołnierze rozrzuceni na różnych frontach wojny, nigdy już do niego nie wrócili. Wielu poległo, wielu pozostało na emigracji i tam zakończyło życie. Także Grodno po 1945 r. znalazło się poza nowymi granicami Polski.

"Grodno hipnotyzuje i przyciąga”. Tak napisał o tym mieście w 1936 r. publicysta „Kuriera Warszawskiego”7. I trudno się z tym nie zgodzić. Rzeczywiście, hipnotyzuje swoim urokiem, klimatem minionych lat, nostalgią ludzi, którzy spędzili w nim najlepsze lata życia i musieli je opuścić, często na zawsze. Przyciąga natomiast swoją historią, w którą wpisuje się garnizon będący jego nieodłączną częścią przez wszystkie lata II Rzeczpospolitej. Garnizon zniknął bezpowrotnie i mimo upływu lat, nadal pozostaje niezasłużenie w cieniu Wilna i Lwowa. Odżywa jedynie we wspomnieniach związanych z tragicznym najazdem sowieckim we wrześniu 1939 r., a jego dzieje są praktycznie nieobecne w polskiej historiografii wojskowej. Jak już wcześniej wspomniano, wstępna analiza dostępnych źródeł wskazuje, jak bogata jest historia Garnizonu Grodno w latach 1921-1939. Jej całościowe opracowanie uwzględniające wszystkie wydarzenia obejmujące lata służby na stopie pokojowej, udział poszczególnych jednostek w wojnie 1939 r. daje wprawdzie możliwości badawcze, ale jest to przedsięwzięcie wymagające żmudnych poszukiwań, nie tylko w polskich zasobach archiwalnych. To ogrom pracy, który jednak warto podjąć, by wypełnić lukę w historiografii i zwrócić uwagę na zapomniany obecnie garnizon, ciężko doświadczony w latach ostatniej wojny.

46 C. Grzelak, Kresy w czerwieni. Agresja Związu Sowieckiego na Polskę w 1939 roku, Warszawa 2001, s. 335-352.; A. JęDRZEJEWSKA, Walczyć czy odstąić? Postawy i dylematy oficerów Obszarów Warownych „Grodno” $i$ „Wilno” we wrześniu 1939 roku, „Acta Universitatis Lodziensis. Folia Historica" 2019 , t. 103, s. 119-132.

${ }^{47}$ J. WIRSKI, W grodzieńskiej restauracji, „Kurier Warszawski. Wydanie wieczorne” 1936, nr 103 , s. 8 . 


\section{BIBLIOGRAFIA}

\section{Źródła archiwalne}

\section{Centralne Archiwum Wojskowe - Wojskowe Biuro Historyczne}

Komenda Garnizonu Grodno, sygn. I.327.16.15.

76 pp, sygn. I.320.76.17.

81 pp, sygn. I.320.81.9-11, I.320.81.13-14, I.320.81.16, I.320.81.19, I.320.81.22-23.

\section{Źródła drukowane}

Berbecki L., Pamiętniki generata broni, Katowice 1959.

Maty rocznik statystyczny 1938, Warszawa 1938.

Nałkowska Z., Dzienniki 1918-1929, Warszawa 1980.

\section{Prasa}

Dnia 23 X b.r. (niedziela) koncertuje w Oficerskim Kasynie Garnizonowym W. Matcużyński. Największy talent wśród mtodych pianistów [ogłoszenie] „Głos Nadniemeński” 1938, nr 21, s. 10.

Dwie donioste uchwaty Rady Miejskiej, „Nadniemeński Kurier Polski” 1924, nr 16, s. 1.

Kin L., Wręczenie karabina maszynowego, „Żołnierz Polski” 1938, nr 13, s. 309.

Nałkowska Z., Grodno, „Tygodnik Ilustrowany” 1936, nr 45, s. 765.

Obywatelstwo honorowe Grodna, „Kurier Warszawski. Wydanie poranne” 1936, nr 20, s. 6.

Odezwa do Sejmików Powiatowych i Magistratów miast wydzielonych Województwa Biatostockiego, „Nadniemeński Kurier Polski” 1924, nr 60, s. 1.

Projekty i postanowienia w sprawie Zamku, „Nadniemeński Kurier Polski” 1924, nr 31, s. 1.

Wirski J., W grodzieńskiej restauracji, „Kurier Warszawski. Wydanie wieczorne” 1936, nr 103, s. 8.

Żądajcie wyrobów Kresowej Fabryki Rowerów i Motocykli „Niemen” [reklama], „Głos Nadniemeński” 1938, nr 1, s. 12. 


\section{Opracowania}

Bieliński P., 29 Dywizja Piechoty, Warszawa 2018.

Czarnowski R.J., Grodno. Zapomniana stolica, Warszawa 2015.

Filipow K., Barwa, herby i godta na odznakach Wojska Polskiego w DOK nr III - Grodno, [w:] $S G O$ „Narew” i GO „Grodno” w wojnie obronnej 1939 r. Materiaty z sesji naukowej „Obchody 65 rocznicy wybuchu II wojny światowej”, Białystok-Przasnysz 2004, s. $87-100$.

Grzelak C.K., Kresy w czerwieni. Agresja Związku Sowieckiego na Polskę w 1939 roku, Warszawa 2001.

Jędrzejewska A., Bezprawa do chwaty? Generat brygady Józef Konstanty Olszyna-Wilczyński (1890-1939). Biografia, Łódź 2018.

Jędrzejewska A., Walczyć czy odstąpić? Postawy i dylematy oficerów Obszarów Warownych „Grodno" i „Wilno” we wrześniu 1939 roku. „Acta Universitatis Lodziensis. Folia Historia” 2019, nr 103, s. 119-132.

Kazak T., Katalog prasy grodzieńskiej, „Rocznik Grodzieński” 2019, nr 5, s. 89-115.

Lisicki J., Strzelcy grodzieńscy, Białystok 1995.

Milewski J.J., Udziat oficerów garnizonu grodzieńskiego w życiu kulturalnym miasta w latach trzydziestych, [w:] Ksiega jubileuszowa Muzeum Wojska 1968-1998, Białystok 1999, s. $195-197$.

Nicieja S.S., Grodzieńscy lekarze wojskowi, [w:] Kresowa Atlantyda. Historia i mitologia miast kresowych, t. 13, Grodno, Wotczyn, Stare Wasiliszki, Żołudek, Mosty, Druskienniki, Opole 2019, s. 137-139.

Pamięć Grodna 1919-1939. Informator wystawy luty-kwiecień 1999, Warszawa 1999.

Waszkiewicz A., Kresowa Fabryka Rowerów i Motocykli „Niemen” „Rocznik Grodzieński” 2019, nr 5, s. 121-130.

Wróblewski J., Armia „Prusy” 1939, Warszawa 1986.

\section{Netografia}

https://harodnia.com/pl/grodno-wczoraj/520-od-zdjecia-z-fotosalonu-do-filmowki (dostęp: 5 I 2012).

https://www.youtube.com/watch?v=uz_mMHIjijA (dostęp: 5 I 2012). 


\title{
Agnieszka Jędrzejewska \\ GRODNO - FORGOTTEN GARRISON OF THE SECOND REPUBLIC OF POLAND
}

\begin{abstract}
Summary. In the years 1921-1939 one of the largest military garrisons operated in Grodno. Its strength and importance was evidenced by the presence of regular troops as well as the authorities and military institutions that had their headquarters in this city. Many famous officers who actively participated in the life of the city were associated with the Grodno garrison. The history of the garrison is full of events such as daily service, matters of training and discipline, education and upbringing of soldiers. It is also a sport and the participation of garrison officers in various events that go beyond their daily duties. Its character and significance changed after the withdrawal of regular military units to fight the Germans, just before the outbreak of World War II. The garrison ceased to exist in September 1939 and did not revive after 1945. The aforementioned extensive subject exceeds the framework of the presented text, therefore only some of the threads are presented. They are only a small fragment of the garrison's history, the history of which is not widely known. Despite the rich source base gathered in the Central Military Archives in Warsaw, in the National Historical Archives of Belarus in Grodno and information contained in the pre-war press, the Grodno garrison's monograph has not yet been created.
\end{abstract}

Keywords: Grodno, Grodno garrison, Polish Army 1921-1939 
